\title{
ТРИ НОВАКОВИЋЕВА СПИСА ПОСВЕЋЕНА АКТУЕЛНИМ ПИТАЮИМА ЛЕКСИКОГРАФСКЕ ПРОБЛЕМАТИКЕ И ЛЕКСИКОГРАФСКЕ ПРАКСЕ ${ }^{* *}$
}

Аутор се у раду бави Новаковићевим списима насталим у периоду од 1878 . до 1893. године. На основу њих дефинишу се лексикографска гледишта Стојана Новаковића посвећена питањима неге српскога језика и актуелној лексикографској проблематици, утврђује његов значај у развоју српске лексикографске мисли.

Кључне ријечи: Стојан Новаковић, лексикографски списи, савремени рјечник српског језика

Оцртавајући улогу и значај Стојана Новаковића у нашој науци о језику, Рајна Драгићевић је успоставила својеврсну параболу која спаја најзначајније личности српске језичке средине на размеђи XIX и XX вијека - Ђуру Даничића, Стојана Новаковића, Љубомира Стојановића и Александра Белића (Драгићевић 2015: 2). На нама није да оцјењујемо чија је улога важнија у србистици као науци, чије дјело има плодоноснији или далекосежнији значај, дубљи или потпунији карактер у њеном цјелокупном развоју. На нама је да дамо скицу за сагледавање значаја Стојана Новаковића у оном сегменту језичке дјелатности који је посвећен „неговању језика српског” и изради рјечника савременог српског језика. Па ипак, прије него што се у жижу интересовања постави наведено прегалаштво овога филолога - жељели смо да о Новаковићу као „великом синтетичару” како га Александар Белић назива, дамо једну управо Белићеву давно изречену оцјену: „Он је био човек знања, човек дела, један дух који невероватно упрошћава све сложености предмета, прагматичар и симплификатор који сагледава пре крај послу неголи што

\footnotetext{
*nedjo.josic@isj.sanu.ar.rs

${ }^{* *}$ Рађено у оквиру пројекта 178009 Лингвистичка истраживања савременог српског језика и израда Речника српскохрватског књижевног и народног језика, који у цјелини финансира Министарство просвете, науке и технолошког развоја Републике Србије.
} 
друго, способан за предузимање крупних научних издавачких предузећа и великих колекторских научних послова" (Белић 1999: 154).

Лексикографска гледишта Стојана Новаковића заметала су се, унапређивала и сазријевала углавном у додиру с Вуковим Српским рјечником, Даничићевом лексикографском праксом, старијом и савременом лексичком грађом српског језика, те у додиру са страним лексикографским подухватима, посебно великим Гримовим Рјечником њемачког језика и Литреовим Рјечником франиуског језика. Новаковићева активност усмјерена на лексикографску проблематику посебно је била згуснута у периоду од 1867 . године (кад отпочиње да се одвија жива сарадња праћена преписком између Ђ. Даничића и С. Новаковића), до 1893. године, периоду када су настали Новаковићеви списи посвећени актуелним питањима лексикографске проблематике и лексикографске праксе. У оцјени Новаковићеве улоге и његовог значаја за развој српске лексикографске мисли неопходно би било да се наведени списи изблиза осмотре и аналитички сагледају. Тако би била утврђена основа за расвјетљавање улоге трију најзначајнијих фигура - Новаковића, Бошковића и Белића као лингвиста који у идејном и теоријско-методолошком смислу стоје на челу Речника српскохрватског књижевног и народног језика, као највећег националног подухвата на пољу српске описне лексикографије.

\section{Први спис: Писмо Стојана Новаковића предсједнику $\boldsymbol{J A 3} У(1878)$}

Овај спис посвећен је свесци насловљеној као Ogled. Rječnik hrvatskoga ili srpskoga jezika. Огледну свеску којом се утемељује наведени рјечник обрадио је и предговор саставио Ђуро Даничић. ${ }^{1}$ Позитивну оцјену Огледа дао је Ф. Миклошић, С. Новаковић и И. Срезњевски, а најопширнију и углавном негативну оцјену дао је представник тзв. загребачке школе Вебер Ткалчевић. ${ }^{2}$ Свој спис Новаковић је упутио предсједнику Академије Фрањи Рачком казујући како је поласкан и како му је част да склопи „низ размишљања и карактеристика" о Даничићеву Огледу. ${ }^{3}$ Ову расправу А. Белић је оквалификовао као нешто „најозбиљније што је о Даничићеву Огледу написано”, те поводом Новаковићева списа устврдио: „Новаковићев синтетички дух желео је нешто више" (Белић 1998: 453). Шта се крије иза Белићеве опште оцјене,

\footnotetext{
${ }^{1}$ Оглед поред предговора (III-VII) садржи списак извора (VIII-XII); надаље је сам рјечник уприличен на тридесетак страна (1-31) с 36 одредница, међу којима је узвику и везнику $а$ и његовим функцијама посвећено 47 стубаца. Међу важнијим одредницама су ријечи алат, бацати, бајачица, бајалаи, бајати, баштина, бесједа, бесједити, биће.

${ }^{2}$ Нешто опширнији преглед оцјена даје Винце 1981: 393-394.

${ }^{3} \mathrm{O}$ неким мање познатим околностима Даничићева преласка у Загреб и његовим односима са Фрањом Рачким, Новаковић говори у једном писму (рекло би се из 1876. године) упућеном Ватрославу Јагићу: „Уз то се ради рата ми сви разиђосмо по границама те је неко време Београд имао мушку популацију сведену веома на мало и заступљену странцима. Тако Ђура дође до мучне невоље, а мудри Фр. Рачки погоди са својом категоричном понудом баш тад. Међутим и са наше стране, од кнеза, чињена му је помоћ” (Јагић 1930: 363).
} 
могуће је открити само ако се Новаковићевој расправи приступи аналитички и с доста пажње. Цијела расправа изнесена на готово педесет страна густо куцаног текста, садржи двије мање-више засебне цјелине, али тако конципиране и срочене да се њихови поједини сегменти међусобно прожимају и допуњују. Прва цјелина могла би да се окарактерише као општи поглед на лексикографску праксу „словенског југа” и новија европска лексикографска достигнућа, друга као критички осврт на Даничићев Оглед.

а. Општи поглед на лексикографску праксу словенског југа и новија европска лексикографска достигнућа. У овом дијелу Новаковић се критички осврће на лексикографска остварења настала од краја XVI до почетка XIX вијека. Рјечнике од Вранчићева Dictionariuma до Стулићева Rječosložja, аутор назива шокачким рјечницима, оцјењујући како су конципирани с циљем да пруже „цјелину” језика. Ипак, у представљању лексичке грађе у њима се снажно осјећају субјективне оцјене њихових састављача: „Они сви стоје, или практиком или теоријом или неодољивом за тадашњу литерарну снагу нискоћом гледишта, сваки у својој тијесној домовини, сваки под потпуном влашћу идеја и уплива оне културе, у којој су се до литерарног развитка узвисили" (Новаковић 1878: 166). Истичући дјело Дубровчанина Микаље Blago jezika slovinskoga (штампано 1649. године) као најснажније остварење, Новаковић даље образлаже да наведени шокачки рјечници уз опште и бројне унутрашње слабости, носе и још једно заједничко обиљежје: то је питање идентитета народа чији вокабулар представљају. Тако се, ма како да се то схвата, Вранчићев поистовјећује са далматинским идиомом, Бјелостјенчев, Јамбрешићев, Волтиђијев и Стулићев са илирским, а Микаљин са словинским. У погледу заступљене лексике у њиховим рјечницима, уз просторна ограничења, он наводи да су се њихови састављачи огријешили и о временску димензију - у рјечнике су уносили онај материјал који су сами научили и знали, а „пространо поље прошлости” остало им је до краја непознато. Крајње уопштено, Стојан Новаковић је њихово опште стање изразио овако: „Ниједан од горе поменутих писаца не бијаше на чисто ни с именом језика, којему лексикографски труд свој посвећаваше, ни с цјелокупним главним карактером, ни с осталом родбином, ни с унутрашњим законима тога језика" (Новаковић 1878: 167).

Представљајући Вуков Српски рјечник из 1818. године, Новаковић је посебно нагласио да Вуково дјело чини велики помак у односу на дотадашњу лексикографску праксу „словенског југа”. Његов аутор „својом радњом отвара савршено нов период” (Новаковић 1878: 169). Према Новаковићевим запажањима, Вук је одрешито рашчистио са рускословенском писаном традицијом претпостављајући овој српски народни језик и језик усмене народне културе као његову књижевну основицу: „Положај језика према родбини, н. пр. према рускоме и староме словенскоме Вук већ исказује тако јасно и прецизно, да то његово исказивање чини епоху у хисторији језика на српском истоку" (Новаковић 1878: 169). Такође, Вук је имао јасну представу о језичким разликама међу идиомима, па је, сходно томе, код великог броја ријечи давао или назначивао њихову дијалекатску перспективу. Али, начелно 
и угрубо речено, прво издање Вукова Рјечника садржи пресјек лексике једног индивидуалног говора, пресјек који Новаковић види као лексички свијет једнога човјека: „У њему је [Српском рјечнику] проматрање једнога човјека, проматрање свакојако без потпуне систематичности и не увијек из близа" (Новаковић 1878: 171) (исп. Ивић 1966: 79). Ипак, уз наведене и бројне друге добре стране Вуковог Рјечника, Стојан Новаковић уочава и неке недостатке. Прије свега, аутор Писма у језику види резултат динамичког прожимања свих његових слојева или „кругова”, те је и за потпунију представу лексичког система једног идиома какав је књижевни језик, неопходно трагати за лексиком различитих области друштвеног живота и рада (Новаковић 1878: 172). Опет, и некако тијесно повезано с овим, Новаковић запажа да је Вуков лексикографски концепт недовољан за пружање цјеловите лексичке слике српског језика, те га је, и поред тога што разграничава појам дијалекатског, потребно системски употпуњавати и у оном правцу који омогућује испољавање дијалекатских лексичких специфичности. Новаковић ово схватање изражава на њему својствен начин: „Један се коријен у једном предјелу - што ће, филолошким језиком говорећи, рећи у једном дијалекту - аклиматише, докле у другом пропадне; у једном потјера мноштво изданака, докле у другоме веома закржљави и једва се у животу задржи " (Новаковић 1878: 172).

б. Критички осврт на Даничићев „Оглед”. Да би успоставио што шири оквир у који се смјешта Даничићев Оллед, да би оправдао или у појединим сегментима довео у питање његове резултате, Новаковић се позива на методолошки и концепцијски најзначајнија европска лексикографска достигнућа тога времена. То је у првом реду Deutsches Wörterbuch браће Грим и и Литреов Dictionnaire de la langue française. За разлику од Нијемаца и Француза који су - констатује Новаковић - у ХІХ вијеку имали „уједињен” књижевни језик (Гримов историјски рјечник утемељен је на споменицима од VII вијека наовамо и лексичкој грађи горњоњемачког дијалекта, Литреов рјечник заснован је на савременој грађи и класичном француском језику до XVII вијека), наш књижевни живот био је посве разједињен (Новаковић 1878: 190). Дијалекатско шаренило и књижевни језик у заснутку, увелико су, међу осталим чиниоцима - сматра Новаковић - усложили природу Даничићевог Огледа.

У спису Писмо Стојана Новаковића предсједнику, углавном су, с осјећањем изразите наклоности према своме учитељу, изнесене добре стране Даничићева Огледа. Уочене недостатке и мањкавости Новаковић је давао с осјећањем такта, развијао их и формулисао с циљем да се будући рјечник научно-методолошки што темељније и шире заснује. Он тако сугерише да би Даничићеве изворе ваљало унеколико проширити, а то проширење могло би да се развија у три правца. Први правац би обухватио дјела која претходе - да употребимо Даничићеву формулацију - „нашем времену”. Ту Новаковић наводи дјела босанских фратара и других приморских писаца код којих је могуће уочити „пробијање на видик језика народнога”, а посебно дјела из источног дијела штокавске територије. Други правац обухватао би дјела савремених писаца. Трећи правац попуне односио би се на грађу народних 
умотворина (поред оних наведених у Даничићевим изворима). Новаковић се надаље противи, ма колико поуздана Даничићева акцентуација била, да се старој лексици, ријечима које су се затрле или изобичајиле у народним говорима, даје акценат по субјективном нахођењу. Он је, дакле, против сваког вида субјективног представљања лексичке грађе (Новаковић 1878: 200).

Заокружујући представу о овом обимном и исцрпном Новаковићевом спису, жељели смо да се посебно истакне она страна Огледа о којој је Новаковић изнио најоштрије замјерке - то је питање етимологије. Осврћући се на тежње Самуела Богомила Линдеа (Stownik jẹzyka polskiego, 1807-1814) и Јосефа Јунгмана (Slovník česko- německý, 1835-1839), чија етимологија углавном није испала „срећно”, аутор се надаље окреће Гримовом и Литреовом рјечнику као обрасцима у којима је етимологија постављена на завидном нивоу. „Браћа Грими старају се, да постање ријечи освијетле с двије стране: поређењем из германскога, и по том поређењем из индоевропскога круга. На то је њихово поређење вриједно угледати се" (Новаковић 1878: 202). Слично поступа и Литре, и тај његов етимолошки поглед пун је ,једре поуке”. Нажалост - сматра Новаковић - Даничић је напустио такав план и окренуо се приказивању коријена као својеврсној етимологији (исп. Винце 1981: 393). У том погледу Даничић је ишао далеко, предалеко. Међу примјерима Новаковић наводи Даничићеву етимологију ријечи бацати. Оцјенивши да је њен развојни пут недовољно потврђен, магловит у Даничићевој грађи, а држећи се начела да је етимологија мање сигурна што се мање ослања на историју ријечи и компарацију, доноси општи закључак: „Недовољан је овај начин тумачења за то, што не показује процеса којим је лексикограф дошао до својих закључака, нити чинилаца, који су ону суму створили; не износи пред нас ону цјелокупну грађу, која је његовим продукцијама за основ служила" (Новаковић 1878: 203).

Ово су били само битнији сегменти Новаковићеве расправе. Пишући о Огледу и поводом њега, образован и речит какав је био, Новаковић је навео бројна запажања о српској националној култури, нашем језику, нашем човјеку. Она су често изражена на најфинији начин, увјерљиво и са пуно духа. А одрешит одговор Фрањи Рачком био је: „да се Ogled прими и уређивање рјечника настави”.

\section{Други спис: Српска краљевска академија и неговаье језика српског (Посланица Академији наука философских) (1888)}

Други обимни спис Стојана Новаковића насловљен као Српска краљевска академија и неговање језика српског, има свечарска обиљежја - припреман је о стогодишњици Вукова рођења, а поднесен на свечаном скупу Српске краљевске академије у септембру 1888. године. Белићево запажање да је „Новаковићев синтетички дух желео [je] нешто више” (изражено поводом списа Писмо Стојана Новаковића предсједнику) (Белић 1998: 453), у 
потпуности оправдава Новаковићева Посланица. Деценија пред њену појаву, у којој пада и дан изненадне Даничићеве смрти (1882), представља период у којем је Новаковић начинио својеврстан заокрет у својој језичкој мисији. Тај период и период непосредно иза њега, некако је и вријеме када се он дефинитивно окреће његовању српске језичке културе у најпотпунијем смислу те ријечи и полагању институционалних оквира за њено унапређивање и подизање. То је некако и вријеме - како то наводи и Радосав Бошковић - када је наш језик постао књижевни, књижевни у најпотпунијем смислу те ријечи. ${ }^{4}$ Новаковићева Посланица Академији наука философских обиман је спис писан специфичним језиком и стилом, спис полемичког карактера, спис оштрих и увјерљивих запажања, ријетких и необичних поређења. Овдје бисмо да се сумирају већ дата запажања о Новаковићевој Посланици (Јошић 2016б), те да се она оснаже још покојим фактом који би откривао њен дубљи и потпунији смисао.

а. Основица књижевног језика. За разлику од Даничићевих филолошких гледишта у којима стара писана језичка заоставштина представља чинилац богаћења народног језичког израза - Новаковић у Посланици у жижу ставља народни језик као општи ослонац за гранање и унапређивање књижевног језика: „Од Стојана Новаковића и његових излагања почело је код нас јасно раздвајање народног језика и народног књижевног језика" (Грицкат 1993: 8). Новаковићева представа о народном књижевном језику сасвим је одређена- то је књижевни језик с дијалекатском основицом, али језик ослобођен оних типичних дијалекатских особености по којима је дијалекте међу собом могуће разликовати и поредити. „Новаковић, дакле, види у књижевном језику једну нарочиту варијанту народног” (Грицкат 1960б: 315). Обрасце таквога језика аутор види нпр. у Вуковом преводу Новога завјета из 1847. године и Даничићевим Приповеткама из Старога и Новог завета из 1850. године.

б. Временска димензија рјечничке грађе. Полазећи од Даничићевог временског разграничења изнесеног у Огледу, Новаковић је у Посланици, спису у којем се заправо нашироко заснива и образлаже идеја о великом описном рјечнику савременог српског језика и скицира његов лексикографски профил, изнио гледиште да писану заоставштину од Доситејевих дјела наовамо ваља употпунити обимном грађом из народних умотворина, али и лексичком грађом преузетом из дјела савремених писаца. „Даничић је - да се послужимо запажањем Е. Фекете - јасно дефинисао деобне међе две епохе у развитку наше језичке историје, на основу кога је, опет, Ст. Новаковић указао на полазне границе од којих [...] будући речник Академије треба да пође” (Фекете 1993: 24). Оправданост за унос савремене лексичке грађе проистиче из гледања на језик као динамички ентитет, као на живо ткиво са свим мије-

\footnotetext{
${ }^{4}$ Последњу деценију XIX вијека Бошковић означава као период када је наш језик добио своју физиономију: „Тек тада почиње његова стабилизација, његово нормализовање; тек тада је он добио књижевну архитектонику; своје стилове, своје језичке стилове; добио је свој стални и устаљени лексички фонд” (Бошковић 1978: 189).
} 
нама у лексици, синтакси, фразеологији, метафоричком изражавању итд. (исп. Грицкат 1993: 8).

в. Дијалекатско тежиште рјечника. Модел књижевног језика утемељен на ,јужном” (херцеговачко-дубровачком) изразу како га је засновао Вук, Новаковићу се чинио као прилично узак оквир за општу културну подлогу савременог српског језика. Новаковић зато прихвата Вуков јекавски израз и језик српских народних умотворина као чиниоце савременог српског књижевнојезичког израза, али ипак сматра да би примат у профилисању књижевног језика требало да имају цивилизацијски и културно најнапредније области. У потоњем периоду то су шумадијска и војвођанска средина. Како у неком књижевном језику обично један дијалекат има примат и суштински одређује тип књижевног језика, а с обзиром на чињеницу да се у западној Србији још у његово вријеме уочавало како ,јужни говор попушта”, Новаковић дијалекатско тежиште „народног књижевног језика” с Вуковог јужног израза премјешта на савремена књижевна достигнућа и говор управо наведених области. Новаковић се у том погледу поводи за Даничићевим схватањима, а Даничић је знао да употреба народног језика у књижевности „почиње баш у његово време, педесетих година прошлога века - у Србији, у ослобођеној Србији" (Бошковић 1978: 189). Потпору за таква гледишта Новаковић такође види у њемачком и италијанском језику, у снази њихових стваралаца (Лутера у Њемачкој, Дантеа и Бокача у Италији) „који су необичном снагом уздигли један дијалекат нада све остале и дали му моћ књижевног језика" (Новаковић 1888: 42). ${ }^{5}$ Уосталом, први спис (Писмо предсједнику), Новаковић је, иако Шапчанин родом, поводећи се за Вуковим и Даничићевим књижевнојезичким начелима, писао јекавским наречјем - други, тј. Посланииу, уобличио је на екавици, приклањајући се тако оном типу књижевног језика који би по логици ствари морао у Србији да има општи примат.

г. Садржинска и тематска страна рјечника. У Посланици упућеној Академији српској, Новаковић се здушно залагао да у нови рјечник српског језика уђе што обимнија грађа која би расвјетљавала различите области живота, рада и духовног стваралаштва. Како је тип књижевног језика био одређен и фундаментална начела о природи рјечника заокружена, Новаковић се окренуо конкретизацији његових лексичких садржаја. Служећи се поучним искуствима Румунске академије у изради рјечника румунског језика, сматрао је да би се истраживање језичких кругова морало одвијати у два сегмента. Један сегмент обухватио би лексику садржану у стручним дјелима (нпр. Јосифа Панчића, Лука Зора, Валтазара Богишића, Владана Ђорђевића), други лексику из народа, за коју би се, како су то већ поучно чинили Румуни, сачинили посебни упитници и разаслали по народу. Аутор Посланице је, дакле, полазио од схватања да је језик слојевит организам, да има свој општи лексикон и своје „кругове”, који даље подразумијевају социјално и терми-

5 ,Један дијалекат - стоји надаље у Новаковићевој Посланици - ако имадне срећу да се изради као књижевни језик, обично потчињава себи све остале ситне дијалекте у около, докле год иду општи основи онога дијалекта, или докле год му се остали сродни дијалекти из околине могу лако прилагодити" (Новаковић 1888: 41-42). 
нолошко раслојавање: „Тога ради језик се расклапа на разне мање или веће кругове и саставне делове по разликама сталежа, послова и радова који чине целину народнога живота" (Новаковић 1888: 80)

д. Појам „српски стил” и назнаке за његово профилисање. У Новаковићеву спису Српска краљевска академија и неговање језика српског, разматрају се бројна питања српског књижевног и народног језика. У њеном уводном дијелу стоје и оне до данас на више мјеста цитиране парадигматичне ријечи: „Иоле књижеван читалац знаће, како се већ са самом Академијом, са самим тако рећи њеним именом спаја мисао о обради језика, о речнику, о уздигнућу језика на виши научни и књижевни значај” (Новаковић 1888: 7). Ауторова синтагма ,уздигнуће језика”, поред размотрених а и неких других параметара битних за уобличење књижевнојезичког израза, свакако подразумијева и његову стилску перспективу. Иако се у Посланици наводе пробрани примјери узорнога стила (Вукови и Даничићеви преводи, те неки ситнији радови Јована Бошковића и Јована Живановића о чистоти језика), Новаковић сматра да би нови рјечник (онако како га он види), морао да представља основицу и за грађење препознатљивог српског стила. Зачетке таквога стила аутор Посланице види у дјелима Доситеја Обрадовића или Јосифа Панчића, уопште у представи о књижевном језику образованом у области источног говора (Новаковић 1888: 63). О особеностима српскога стила мало се шта надаље каже, али је сасвим очигледно да аутор Посланице појам стила уско везује с избором „најправилнијега и најобичнијега у језику". Стилска перспектива књижевног језика пред крај XIX вијека тек је могла да се назре. Пред науком о језику стајали су крупни задаци с цјеловитим и добро заснованим лексиконом на челу, чија би обрада почивала „на литерарним потребама, а не лингвистичким” (Грицкат 1988: 29), лексиконом који би показао особености језика и „његове унутрашње интенције” (Грицкат 1996: 31). За лексиконом би слиједило проучавање реченице и њених синтаксичких чланова, разрада фразеологије и свих оних језичких средстава која служе за суптилно, танано исказивање мисли. „Докле се год то не уради - наводи Новаковић - неће се моћи пречистити ни изградити српски стил” (Новаковић 1888: 37-38).

На крају да се поглед на овај спис сажме у реченицу-двије: Новаковићева расправа Српска краљевска академија и неговање језика српског представља својеврсни манифест, пролегомену нове лексикографске мисли код Срба. У њој је аналитички и критички сагледано стање српскога језика у XIX вијеку и успостављен природан оквир за његов развој, оквир у чијем је средишту програм израде великог рјечника савременог српског језика као најпречи и најважнији Академијин задатак. 


\section{Трећи спис: Предлог Српској краљевској академији да се отпочне купљење грађе за академијски Српски Речник (1893)}

Трећи спис „учињен” је Српској краљевској академији у априлу 1893. године. То је краћи спис штампан на непуних десет стубаца и битно другачији од претходна два. Предлог (како би се могло закључити и из самога наслова), нема оних полемичких тонова, оне жустрине у изношењу гледишта, танане анализе лексикографске проблематике и снажне аргументације што иде уз њу. Иако се у више наврата у овом спису позива на своју Посланицу, Новаковић то овдје чини само како би најважнија гледишта о српском језику и његовом развојном путу у XIX вијеку још једанпут истакао на тако важном мјесту, како би Српској краљевској академији још једанпут предочио какав би то значај за науку и књижевност, за просвету и образовање, за свеколики друштвени и јавни живот нашега народа имао рјечник савременог језика, и каква би улога Академије била у свему томе. У вези са тим навешћемо један веома важан цитат из Новаковићева Предлога: „Задатак новога Српског Речника, којега би израду имала да почне спремати наша Академија, био би баш у томе, да исцрпе и да с нарочитом пажњом лексикографски обради баш ову другу страну рада на тековинама за српски народно-књижевни језик, а то учини више у књижевно-лингвистичком него ли у научно-лингвистичком правцу [...] Тиме би Академија, по природној задаћи својој, извршила своју историјску мисију у образовању језика српског, а срећно и успешно извршење те мисије имало би огромних последица по свима крајевима Словенскога Југа" (Новаковић 1893: 5).

Надаље у Предлогу Новаковић даје конкретна упутства о прикупљању и ексцерпцији грађе, о њеном исписивању и довођење у ред. При том се позива на поучне примјере који су пратили сличну лексикографску активност: на Даничићеве листове међу страницама Вуковог Рјечника с ријечима које се не налазе у Вука; на нарочита питања која је Валтазар Богишић припремио за прикупљање правних обичаја у народу; на упитник што је Румунска академија користила при прикупљању ријечи за свој рјечник (исп. Белић 1959: IX). Међутим, Новаковић је замислио да се такви замашни, озбиљни и одговорни послови повјере посебном тијелу. Зато предлаже да се у оквиру Српске краљевске академије као носилац посла установи Лексикографски одсек. Тако је напокон у окриљу Академије створен институционални оквир и отпочела жива лексикографска активност. Чин стварања Лексикографског одсека и убрзана активност на стварању Српског речника (како га је Новаковић назвао) били су у складу с европским научним струјањима у којима се посебна пажња поклањала националним културним вриједностима (исп. Радовић-Тешић 2009: 207).

Остало нам је на крају да се с неверицом упитамо: како је могуће (када се српска лексикографска мисао од Вука наовамо углавном спотицала о сопствене слабости, када се тек заснивао наш књижевни језик, а славистика била на ниском степену развоја) - како је то могуће да је неко тако моћно сагледао лексикографску проблематику српског језичког поднебља, тако поуздано 
скицирао развојни пут описне лексикографије код Срба у XX вијеку и фактички утемељио обимну лексикографску дјелатност у крилу Српске краљевске академије, чији је плод данашњи Речник српскохрватског књижевног и народног језика (или Речник САНУ) као највећи национални лексикографски пројекат!? И одмах да се каже: могуће је, јер је Новаковић био свестран, научник за велике синтезе, визионар, или како се А. Белић изразио - „човек знања, човек дела [...] способан за предузимање крупних научних издавачких предузећа" (Белић 1999: 154). Приклањајући се Белићевој оцјени о Новаковићевом мјесту у српској лингвистици, Милка Ивић је била још одређенија: Новаковић је био „први Србин који је књижевнојезичку проблематику умео дубље сагледати и у том сагледавању антиципирати неке важне сазнајне видике потоњег столећа" (Ивић М. 1997: 117).

\section{ЛИТЕРАТУРА}

Белић 1926: Александар Белић, Српски речник књижевнога и народнога језика, Белићева оставштина, Архив Српске академије наука, Београд, $1-126$.

Белић 1959: Александар Белић, Речник српскохрватског књижевног и народног језика, Увод (аутор увода: Александар Белић), књ. 1, стр. VIIXXVI.

Белић 1998: Александар Белић, „Стојан Новаковић у својим лингвистичко-филолошким делима", Изабрана дела Александра Белића, том 6, Београд: Завод за уџбенике и наставна средства, 445-464.

Белић 1999: Александар Белић, „Наши учитељи”, Изабрана дела Александра Белића, том 8, Београд: Завод за уџбенике и наставна средства, 146-157.

Бошковић 1978: Радосав Бошковић, „Ђуро Даничић и књижевни језик наш”, Одабрани чланци и расправе, Титоград: Црногорска академија наука и умјетности, 187-190.

Винце 1981: Zlatko Vince, „Odjek Daničićeve koncepcije Akademijina Rječnika”, Зборник о Ђури Даничићу, Београд: Српска академија наука и уметности - Загреб: Југославенска академија знаности и умјетности, 391-400.

Грицкат 1960а: Ирена Грицкат, „Академијски речници и њихови задаци (I део)", Наш језик, X/3-6, 88-100.

Грицкат 1960б: Ирена Грицкат, „Академијски речници и њихови задаци (II део)", Наш језик, X/7-10, 212-227.

Грицкат 1988: Ирена Грицкат, „Речник Српске академије наука и уметности - почеци, лик, перспективе", Глас САHУ, CCCLII (Одељење језика и књижевности, књ. 13), Београд, 25-39.

Грицкат 1993: Ирена Грицкат, „Стогодишњица лексикографског рада при Српској академији наука и уметности”, Сто година лексикографског рада у САНУ (зборник радова), Београд: САНУ и Институт за српски језик САНУ, 5-13. 
Грицкат 1996: Ирена Грицкат-Радуловић, „Наука о језику у делатности Академије", Глас CAHУ, CCCLXXIX, Српска академија наука и уметности (Одељење језика и књижевности, књ. 15), Београд, 1-83.

Драгићевић 2015: Рајна Драгићевић, „Стојан Новаковић као лингвиста”, Наш језик, XLVI/3-4, 1-9.

Ивић 1966: Павле Ивић, „О Вуковом Рјечнику из 1818. године”, Сабрана дела Вука Караџића, књ. II, Београд: Просвета-Нолит, 19-188.

Ивић 1998: Павле Ивић, Преглед историје српског језика, Целокупна дела, књ. VIII, Нови Сад: Издавачка књижарница Зорана Стојановића.

Ивић М. 1997: Milka Ivić, O Vukovom i vukovskom jeziku, Zemun: Biblioteka XX vek; Beograd: Čigoja štampa.

Јагић 1930: Ватрослав Јагић, Спомени мојега живота, књ. I, Београд.

Јошић 2016а: Неђо Јошић, „Белићева лексикографска гледишта и Речник САНУ', Научни састанак слависта у Вукове дане, 45/1, 63-72.

Јошић 2016б: Неђо Јошић, „Новаковићева Посланииа о његовању језика српског - њен карактер и значај за развој српске лексикографске мисли”, Наш језик, XLVII/1-2, 59-71.

Новаковић 1878: „Glasovi o Ogledu rječnika: Pismo Stojana Novakovića predsjedniku”, Rad JAZU, sv. XLV, Zagreb, 165-213.

Новаковић 1888: Стојан Новаковић, „Српска краљевска академија и неговање језика српског (Посланица Академији наука философских)", Глас Српске краљевске академије, св. Х, Београд, 5-87.

Новаковић 1893: Предлог Српској краљевској академији да се отпочне купљење грађе за академијски Српски Речник, Посебно издање (прештампано из листа Јавор), Земун: Штампарија Јове Карамате.

Оглед: Ogled. Rječnik hrvatskoga ili srpskoga jezika. Na svijet izdaje Jugoslavenska akademija znanosti i umjetnosti. Obrađuje Gj. Daničić, Zagreb: Dionička tiskara, 1878.

Радовић-Тешић 2009: Милица Радовић-Тешић, C речима и речником, Београд: Учитељски факултет.

Речник САНУ: Речник српскохрватског књижевног и народног језика, књ. 1-19, Српска академија наука и уметности, Београд 1959-2014.

Фекете 1993: Егон Фекете, „О Речнику српскохрватског књижевног и народног језика САНУ”, Сто година лексикографског рада у САНУ (зборник радова), Београд: САНУ и Институт за српски језик САНУ, 21-49. 


\section{Neđo Jošić \\ THREE NOVAKOVIĆ'S MANUSCRIPTS DEDICATED TO CURRENT ISSUES OF LEXICOGRAPHIC PROBLEMS AND LEXICOGRAPHIC PRACTICE}

\section{Summary}

Novaković's manuscripts dedicated to current issues of lexicographic problems and lexicographic practice of his time present the fundamental basis for the development of lexicographic ideas and lexicographic views among the Serbs. In his Pismo (1878), the author raised the questions of the lexicographic problems of the Slovene south and gave a review of Daničićev's Ogledi; in Poslanica (1888) Novaković delineated a natural linguistic framework for the development of the Serbian language focused on the programme of the compilation of contemporary descriptive dictionary; in Predlog (1893) he initiated the establishment of the Lexicographic department and provided specific guidelines for compilation of the Srpski Rečnik (The Dictionary of the Serbian Langauge). Expertly outlining the developmental path of the Serbian language and the Serbian descriptive lexicography in the twentieth century, Novaković conceptually and practically became its head; the period of contemporary lexicographic understanding among the Serbs starts with Novaković.

Key words: Stojan Novaković, lexicographic manuscripts, contemporary disctionary of the Serbian language. 